\title{
Demografiese struktuurveranderinge en die invloed daarvan op onderwys en wetenskapsbeoefening
}

\begin{abstract}
INLEIDING
Demografiese struktuurveranderinge soos hoë geboortekoerse by sommige bevolkingsgroepe en laer groeikoerse by ander, immigrasie en emigrasie van veral hoëvlakmensekrag en interne bevolkingsverskuiwings, het verreikende implikasies vir die onderwys en wetenskapsbeoefening van 'n land. Verder behoort ekonomiese en tegnologiese veranderinge in opleiding en navorsing gereflekteer te word.

In hierdie kort oorsig word enkele van die belangrikste bevolkingsveranderinge en die invloed daarvan, veral op die universiteitswese en wetenskapsbeoefening, aangetoon.
\end{abstract}

\section{GETALLE - FEITLIK ONBEREIKBARE AANSPRAKE}

Teenoor ' $n$ stagnante of selfs negatiewe ekonomiese groeikoers oor die afgelope paar jaar, groei die antal kliënte in die onderwys met meer as $4 \%$ per jaar. Oor die afgelope paar jaar het studentegetalle aan universiteite met gemiddeld 5\% per jaar toegeneem, terwyl die groei aan technikons $17 \%$ per jaar was. Die besteding van meer as $20 \%$ van die totale staatsbesteding aan onderwys (van die hoogste in die wêreld) kan nie verhoog word nie. Dit is dus duidelik dat "meer van dieselfde" nie die toename in die aantal nuwe leerders kan akkommodeer nie. Na raming sal die totale skoolbevolking van die RSA en die TBVCstate 10,3 miljoen in 1992 tel. ${ }^{1}$ Hierdie syfer sal tot net meer as 14 miljoen teen die jaar 2000 aangroei.

Tans (1991) maak swart leerlinge $79,7 \%$, blankes $9,4 \%$, kleurlinge 8,6\% en Asiërs 2,3\% van die totale skoolbevolking uit. Swart leerlinge se getalle groei egter tans teen meer as 400000 per jaar en sal teen die einde van die eeu met 700000 per jaar toeneem. Die getal blanke leerlinge ( 927000 teen 1991) sal 'n dalende neiging tot 1994 toon om dan weer geleidelik te styg tot net minder as 1 miljoen teen die jaar 2000. Kleurlinge en Asiërs se getalle neem geleidelik toe. Voorafgaande bring mee dat swart leerlinge teen die jaar 2000 ongeveer $85 \%$ en blanke leerlinge net ongeveer $7 \%$ van die skoolbevolking sal uitmaak.

Verskeie faktore dra daartoe by dat daar 'n baie swak deurvloei van veral swart leerlinge van die primêreskoolfase na die senior sekondêrefase is. Teen 1990 was $48,8 \%$ van die totale aantal swart leerlinge in die junior primêreskoolfase en het net 7,7\% die senior sekondêreskoolfase bereik. Vergelykende syfers vir blankes was $34,9 \%$ en $15,6 \%$ onderskeidelik. ${ }^{2}$

\section{MENSEKRAGVUORSIENING EN KWALIFIKASIETENDENSE}

Voorafgaande tendense het verreikende implikasies vir hoëvlakmensekragvoorsiening en tersiêre onderwys. Teen 1990 het 27900 blanke leerlinge matriekvrystelling ver- werf teenoor 21000 swartes, 4500 kleurlinge en 6600 Asiërs. Na raming sal die getal blankes op ongeveer 25000 per jaar stabiliseer, terwyl swart getalle mag aangroei tot 130000 per jaar teen die jaar 2000.

Die rassesamestelling van studente aan universiteite en technikons sal drasties verander. Van die net meer as 300000 universiteitstudente in 1990 het blankes ongeveer $51 \%$ uitgemaak - 20 jaar gelede was dié syfer meer as $70 \%$ ! Van die 84000 technikonstudente in 1990 was $65 \%$ blank. Ook dit sal drasties verander. ${ }^{3} \mathrm{Om}$ hierdie eerstegeslag universiteiten technikonstudente met nuwe leerbehoeftes, en waarvan ouers of familie nooit aan tersiêre inrigtings gestudeer het nie, te akkommodeer, sal besondere eise aan dié inrigtings stel.

Differensiële bevolkingsgroei veroorsaak tans dispariteite in die onderwys. Daling in die blanke leerlingtal veroorsaak dat goed gekwalifiseerde blanke onderwysers sonder werk is. Tot die jaar 2000 moet daar ' $n$ toename van $\mathbf{1 2 5} 000$ onderwysers wees om 'n onderwyser-leerlingverhouding van 1:35 vir swartes te bewerkstellig. Hierby moet 84000 onderwysers getel word wat tans in diens is maar nie toepaslik gekwalifiseer is nie.

Bevolkingsverskuiwing van die suide na die noorde en noordoostelike gedeelte van die land, vanaf die platteland na stad en vanuit die groot metropolitaanse binnekerns na die periferie, veroorsaak dat skole en onderwyskolleges veral vir blankes leeg of gedeeltelik onbenut word. Ook universiteite en technikons sal die gevolge van dié verskuiwings nie ontsnap nie.

Jaarliks word meer as 40000 grade en diplomas aan universiteite verwerf, waarvan een derde nagraadse grade en diplomas is. ${ }^{4}$ Die aantal grade in die natuurwetenskappe, landbou, ingenieurswese en lettere en wysbegeerte toon egter 'n relatiewe daling. ${ }^{5}$ Van die belangrikste redes hiervoor is die groter belangstelling van veral hoë presteerders in die professionele rigtings en die groei in ekonomiese en bestuurswetenskappe, opvoedkunde en paramediese rigtings. Van al die grade wat verwerf word, is slegs $1,8 \%$ in die wiskundige wetenskappe. Alberts ${ }^{6}$ wys daarop dat van elke 100 blanke kinders wat gebore word, 33 matrikulasievrystelling verwerf, 30 'n graad en 2,7 'n graad in natuurwetenskappe en ingenieurswese behaal. Hierdie tendens moet eventueel sy neerslag vind in ons wetenskaplike vermoë om op ekonomiese gebied met die res van die wêreld te kompeteer.

Minder as die helfte van die onderwysers in natuurwetenskappe en skeikunde aan blanke skole beskik oor die minimum aanvaarbare kwalifikasies in fisika en/of chemie. Wat wiskunde-onderwysers betref, het $20 \%$ geen na-sekondêre opleiding in wiskunde nie. 'n Nuwe strategie vir onderwysersopleiding en -heropleiding het dringend geword en sal in 1992 deur die Suid-Afrikaanse Raad vir Onderwys vir kommentaar gepubliseer word. 


\section{IMMIGRASIE EN EMIGRASIE}

Aan die begin van die tagtigerjare het buitelandse wetenskaplikes 'n relatief groot persentasie van die navorsers van dic wetenskaplike rade soos die WNNR uitgemaak, terwyl buitelandse dosente en navorsers groot insette by universiteite gemaak het. Die situasie het oor die afgelope aantal jare drasties verander en die RSA het baie meer hoëvlakmensekrag verloor as wat deur emigrasie gewen is.

In 1982 het 45784 immigrante na Suid-Afrika gekom. Daarna het dit sterk afgeneem om 'n laagtepunt van 6994 in 1986 te bereik en weer tot 14499 in 1990 te styg. ${ }^{7}$ Wat ingenieurs (insluitende argitekte en ingenieurstegnici) betref, het 449 in 1986 die land verlaat, terwyl die immigrante 238 getel het. Dus 'n verlies van 211. Die situasie het egter verander want alhoewel 274 persone in dié beroepsgroep die land in 1990 verlaat het, het 655 hulle in die land kom vestig.

Wat opvoedkundiges (waaronder dosente) betref, is daar nog steeds aansienlike getalle wat die land verlaat, alhoewel die getal van 391 in 1986 tot 164 in 1990 gedaal het. Die syfers vir die mediese beroep verdien nadere aandag. Alhoewel die immigrasiesyfers na 1986 begin toeneem het en emigrasiesyfers 'n afname toon, verteenwoordig emigrerende medici 'n steeds groter persentasie van die ekonomies bedrywige persone wat die land verlaat.

Voorafgaande tendense het tot ' $n$ mindere of meerdere mate ' $n$ invloed op navorsing en ontwikkeling. Bibliomatiese en situasie-analises wat deur Pouris ${ }^{8}$ gedoen is, toon onder andere die volgende ten opsigte van natuurwetenskappe aan: biologiese wetenskappe is van die mees vitale dissiplines en groei vinnig, terwyl kliniese geneeskunde sterk is en middelmatig groei. Aardwetenskappe en ruimtenavorsing toon 'n dalende neiging. Chemie, ingenieurswese en tegnologie beklee middelposisies. "Physics, mathematics and biomedical research appear to be the weakest South African disciplines. As they are of strategic importance for the long-term economic welbeing of the country, they require particular attention."

\section{SLOTBESKOUING}

Demografiese faktore speel ' $\mathrm{n}$ beslissende rol by die bepaling van 'n wetenskapsbeleid van enige land. Vanweë demografiese struktuurveranderinge in die RSA is die tockoms nie sonder meer ' $n$ voortsetting van die verlede nie. Die getallegroci veroorsaak dat die huidige onderwysstelsel, hoofsaaklik 'n Westerse stelsel, nie bekostigbaar is nie. 'n Veel eenvoudiger en leniger stelsel, met klem op basiese onderwysbeginsels, sal ingestel moet word. ${ }^{9}$ Wat die universiteitswese betref, sal op basiese onderrig en navorsing gekonsentreer moet word. Universiteite sal nie kan voortgaan om, soos in die verlede, omvattende inrigtings te wees nie, maar sal moet konsentreer op die terreine waarop uitnemendheid bereik kan word. Veel groter finansiële bydraes sal deur individue, ouers en die private sektor gemaak moet word.

P. SMIT

\section{LITERATUURVERWYSINGS}

1. Research Institute for Educational Planning (1990). Education and man power development 1990. 11. Universiteit van dic Oranje-Vrystaat. Bloemfontein, p. 12

2. Research Institute for Education Planning (1990). Education and manpower development 1990, I1. Universiteit van die Oranje-Vrystaat, Bloemfontein, p. 6

3. Onderwysrealiteite in Suid-Afrika. (1990). Departement van Nasionale Opvoeding, Pretoria, 1991, p. 17.

4. Smit. P. (1990). Wetenskapsbeoefening aan ons universiteite, Tyydskrif vir Geesteswetenskappe, 30(4), p. 331-350.

5. Smit, P. (1991). Die universiteit as unieke vennoot in die opleidingsvennootskap, Mannekrag en ontwikkeling vir die nuwe Suid-Afrika. Vol. 3. Nasionale Opleidingsraad, Pretoria, p. 341

6. Alberts, L. (1989). Op weg na in tegnologiebeleid. Hendrik van der Bijl-herdenkingslesing, Universiteit van Pretoria, Pretoria.

7. Sentrale Statistiekdiens. Verslae oor toerisme en emigrasie. Staatsdrukker, Pretoria.

8. Pouris, A. (1988). Assessing basic research in South Africa, $S$ A Journal of Science, 84, p. 546.

9. Onderwysvernuwingstrategie. (1991). Besprekingsdokument. Departement van Nasionale Opvoeding. 